\title{
Research on Long-term Performance of Private Placement of A-share Listed Companies in China
}

\author{
Jiaqi Jin $^{\text {a, }}$, Yucan Liu \\ School of Economics and Management, Nanjing University of Science and Technology, Nanjing, China \\ a13260286992@163.com, b243230184@qq.com \\ *Corresponding author
}

Keywords: private placement; long-term financial performance; factor analysis

\begin{abstract}
This paper selects A-share listed companies successfully implementing private placement from 2015 to 2017 in Shanghai and Shenzhen as research sample. (Data source: Wind Information) Sample of ST and *ST listed companies issuing private placement is eliminated; sample of B-share companies issuing additionally A-share, A-share companies issuing additionally H-share and $\mathrm{H}$-share companies issuing additionally A-share is eliminated; sample of financial listed companies issuing private placement is eliminated; retain all additional issuances that meets the additional issuance and that have not been reissued during the event period; sample of the major events influencing share price (significant asset restructuring, long-term suspension of major events, suspension of listing, issuance of convertible bonds, public additional issuance of new shares) occurred during the event period is eliminated; sample of financial data and transaction data that cannot be obtained is eliminated. This paper selects 9 financial indicators to conduct factor analysis, build and verify evaluation model of financial performance in the year of additional issuing, and the year before and after the year of additional issuing. The results show that private placement can increase the long-term performance of companies.
\end{abstract}

\section{Model selection:}

Factor analysis is adopted in this paper, dimensionality reduction on 9 financial indicators selected is performed, several common factors are extracted, and scores of these common factors and composite scores of each sample company are calculated to analyze the influence of private placement on business performance of listed companies.

The calculation is performed according to Equation (1).

$$
F=\frac{A_{1} \times F_{1}+A_{2} \times F_{2}+A_{3} \times F_{3}+\cdots}{M}
$$

In Equation (1), $F$ is the composite score of sample companies in a certain year, $M$ is the cumulative variance contribution rate of $N$ common factors, $A_{n}$ is the variance contribution rate of the $N^{\text {th }}$ common factor, and $F_{n}$ is the score of the $N^{\text {th }}$ common factor.

\section{Introduction}

On May 8, 2006, the China Securities Regulatory Commission promulgated the Management Methods for Securities Issuance of Listed Companies, which stipulates that "listed companies may issue securities, which may be issued public to specific targets or not." This provision laid the legal foundation for the application of private placement method in China's capital market, and the refinancing of listed companies in China has once again started on a large scale. In the third quarter of 2017, 102 A-share listed companies completed private placements, and the fundraising scale reached 204.083 billion yuan. 114 A-share listed companies issued private placement plan, which is expected to raise 364.635 billion yuan. Because private placement has not started in China for a long time, many scholars in China have less empirical analysis and research data on private placement, and most of these data focus on the announcement effect, the motivation and discount 
price, etc. of private placement. However, there are relatively few studies on the financial performance of private placement. Therefore, after the private placement has become a mainstream trend, it is of theoretical and practical significance to study the long-term performance of A-share listed companies in China.

\section{Selection of Sample Data and Design of Indicator System}

\subsection{The selection of sample data}

This paper selects A-share listed companies successfully implementing private placement from 2015 to 2017 as research sample. The sample data comes from Wind database, which excludes financial listed companies because they implement the financial system, and excludes $S T, S T^{*}$ companies because these companies are very risky. After screening, this paper finally obtains the financial indicator data of 134 A-share listed companies.

\subsection{The selection of indicator system}

The indicator system is shown below in Table 1.

Table 1 The selection of indicator system

\begin{tabular}{l|c}
\hline \multirow{2}{*}{ solvency } & current ratio \\
\cline { 2 - 2 } & quick ratio \\
\cline { 2 - 2 } operation capacity & asset-liability ratio \\
\cline { 2 - 2 } & flow asset-liability ratio \\
\hline \multirow{2}{*}{ profitability } & total assets turnover \\
\cline { 2 - 2 } Capacity of cash flow & earnings per share \\
\cline { 2 - 2 } & return on equity \\
\hline
\end{tabular}

\section{Process of Empirical Research}

\subsection{Data normalization and standardization}

Some raw data needs to be normalized before factor analysis. The asset-liability ratio in the financial indicators selected is a reversal indicator, which needs to be normalized. The processing method is to calculate the reciprocal. After the data normalization, it is necessary to standardize the data with a mean of 0 and a variance of 1 , eliminating the difference in dimensions and comparing each financial indicator among listed companies. Descriptive Statistics are shown in Table 2.

Before performing factor analysis, the data should be conducted the applicability test. The purpose of the test is to ensure that there is a certain degree of correlation between the variables in order to extract the common factors. The null hypothesis of Bartlett's sphericity test is that the correlation matrix is a unit matrix. If the $\mathrm{P}$ value of the test result is 0 , the null hypothesis can be rejected and the test can be passed. The closer the KMO test value is to 1, the greater the correlation between the variables, and thus the more suitable for factor analysis. In general, factor analysis can be performed with a KMO value above 0.5. In this paper, Bartlett sphericity test and KMO test are carried out on the measurement indicator data of the sample in the three years $(2015,2016,2017)$, and the results of both tests indicate that there is a certain correlation between variables, which can be analyzed with factor analysis. Specific test results are shown in Table 3, 4, and 5.

From the results of the applicability test, the data of private placements in 2015, 2016 and 2017 are suitable for factor analysis.

\subsection{Factor analysis}

Taking 2015 as an example, as can be seen from Table 6, the first three eigenvalues are greater than 1 , respectively $3.866,2.102,1.321$, and the cumulative contribution rate is $80.990 \%$, indicating 
that these three factors can explain $80.990 \%$ of the total variance, which can be considered as reflecting most of the original material. Therefore, this paper selects three common factors.

Table 2 Descriptive Statistics

\begin{tabular}{|c|c|c|c|c|c|}
\hline & $\begin{array}{l}\text { number } \\
\text { of cases }\end{array}$ & Minimum & Maximum & Average & $\begin{array}{l}\text { Standard } \\
\text { deviation }\end{array}$ \\
\hline current ratio of 2015 & 132 & -.84466 & 6.84748 & .0000000 & 1.00000000 \\
\hline current ratio of 2016 & 133 & -.82362 & 9.36074 & .0000000 & 1.00000000 \\
\hline current ratio of 2017 & 133 & -.89015 & 8.70388 & .0000000 & 1.00000000 \\
\hline quick ratio of 2015 & 132 & -.79199 & 6.79916 & .0000000 & 1.00000000 \\
\hline quick ratio of 2016 & 133 & -.70765 & 9.56478 & .0000000 & 1.00000000 \\
\hline quick ratio of 2017 & 133 & -.73925 & 8.74780 & .0000000 & 1.00000000 \\
\hline reciprocal of asset-liability ratio in 2015 & 134 & -.91890 & 5.54716 & .0000000 & 1.00000000 \\
\hline reciprocal of asset-liability ratio in 2016 & 134 & -.66010 & 8.26033 & .0000000 & 1.00000000 \\
\hline reciprocal of asset-liability ratio in 2017 & 134 & -.88528 & 5.89406 & .0000000 & 1.00000000 \\
\hline current asset turnover of 2015 & 132 & -1.21445 & 7.56968 & .0000000 & 1.00000000 \\
\hline current asset turnover of 2016 & 132 & -1.12237 & 6.98905 & .0000000 & 1.00000000 \\
\hline current asset turnover of 2017 & 132 & -1.10289 & 8.61718 & .0000000 & 1.00000000 \\
\hline total assets turnover of 2015 & 134 & -1.47943 & 4.91867 & .0000000 & 1.00000000 \\
\hline total assets turnover of 2016 & 134 & -1.40522 & 4.54692 & .0000000 & 1.00000000 \\
\hline total assets turnover of 2017 & 134 & -1.33711 & 6.70640 & .0000000 & 1.00000000 \\
\hline earnings per share of 2015 EPS & 134 & -10.64001 & 1.08808 & .0000000 & 1.00000000 \\
\hline earnings per share of 2016 EPS & 134 & -2.82323 & 3.86332 & .0000000 & 1.00000000 \\
\hline earnings per share of 2017 EPS & 133 & -3.09784 & 5.69008 & .0000000 & 1.00000000 \\
\hline return on equity of $2015 \mathrm{ROE}$ & 133 & -6.64288 & 1.92589 & .0000000 & 1.00000000 \\
\hline return on equity of $2016 \mathrm{ROE}$ & 134 & -5.08587 & 5.10916 & .0000000 & 1.00000000 \\
\hline return on equity of $2017 \mathrm{ROE}$ & 134 & -3.89402 & 4.05919 & .0000000 & 1.00000000 \\
\hline cash ratio of 2015 & 132 & -.67446 & 7.19446 & .0000000 & 1.00000000 \\
\hline cash ratio of 2016 & 132 & -.82554 & 5.34763 & .0000000 & 1.00000000 \\
\hline cash ratio of 2017 & 132 & -.66073 & 9.04388 & .0000000 & 1.00000000 \\
\hline Net cash flow per share from operating activities in 2015 & 134 & -2.13180 & 4.24795 & .0000000 & 1.00000000 \\
\hline Net cash flow per share from operating activities in 2016 & 134 & -5.67724 & 3.94187 & .0000000 & 1.00000000 \\
\hline Net cash flow per share from operating activities in 2017 & 134 & -9.70211 & 2.23564 & .0000000 & 1.00000000 \\
\hline Number of effective cases(in line) & 130 & & & & \\
\hline
\end{tabular}

Table 3 Bartlett test and KMO test results in 2015

\begin{tabular}{l|c|c}
\hline Kaiser-Meyer-Olkin measure of sampling adequacy & & 0.691 \\
\hline Bartlett test of sphericity & approximate chi-square & 1247.240 \\
\hline & degree of freedom & 36 \\
\hline & significance & 0 \\
\hline
\end{tabular}

Table 4 Bartlett test and KMO test results in 2016

\begin{tabular}{c|c|c}
\hline Kaiser-Meyer-Olkin measure of sampling adequacy & & 0.670 \\
\hline Bartlett test of sphericity & approximate chi-square & 1121.315 \\
\hline & degree of freedom & 36 \\
\hline & significance & 0 \\
\hline
\end{tabular}

Table 5 Bartlett test and KMO test results in 2017

\begin{tabular}{c|c|c}
\hline Kaiser-Meyer-Olkin measure of sampling adequacy & & 0.604 \\
\hline Bartlett test of sphericity & approximate chi-square & 1141.180 \\
\hline & degree of freedom & 36 \\
\hline & significance & 0 \\
\hline
\end{tabular}


Table 6 The explanation of total variance in 2015

\begin{tabular}{|c|c|c|c|c|c|c|}
\hline \multirow[b]{2}{*}{ component } & \multicolumn{2}{|c|}{ Initial Eigenvalues } & \multicolumn{4}{|c|}{ Extract Sums of Squared Loadings } \\
\hline & total & $\begin{array}{l}\text { Variance } \\
\text { percentage }\end{array}$ & $\begin{array}{l}\text { accumulation } \\
\%\end{array}$ & total & $\begin{array}{l}\text { Variance } \\
\text { percentage }\end{array}$ & $\begin{array}{l}\text { accumulation } \\
\%\end{array}$ \\
\hline 1 & 3.866 & 42.959 & 42.959 & 3.866 & 42.959 & 42.959 \\
\hline 2 & 2.102 & 23.352 & 66.311 & 2.102 & 23.352 & 66.311 \\
\hline 3 & 1.321 & 14.679 & 80.990 & 1.321 & 14.679 & 80.990 \\
\hline 4 & .921 & 10.228 & 91.218 & & & \\
\hline 5 & .305 & 3.390 & 94.609 & & & \\
\hline 6 & .219 & 2.432 & 97.041 & & & \\
\hline 7 & .198 & 2.202 & 99.243 & & & \\
\hline 8 & .062 & .687 & 99.930 & & & \\
\hline 9 & .006 & .070 & 100.000 & & & \\
\hline
\end{tabular}

The rotated rotation component matrix is obtained by factor rotation, as shown in Table 7 and the component score coefficient matrix in 2015 is shown in Table 8. The three factors can be named by the rotated matrix of rotational components and interpreted economically, which shall be conducted scientifically from a comprehensive perspective. Table 9, table 10, table 11 and table 12 show the situation in 2016 and 2017, respectively.

Table 7 Rotation component matrix in 2015

\begin{tabular}{llll}
\hline & \multicolumn{3}{l}{ component } \\
\cline { 2 - 4 } & 1 & 2 & 3 \\
\hline current ratio of 2015 & .982 & .083 & -.073 \\
\hline quick ratio of 2015 & .983 & .085 & -.060 \\
\hline reciprocal of asset-liability ratio in 2015 & .936 & .075 & -.055 \\
\hline current asset turnover of 2015 & -.121 & .030 & .939 \\
\hline total assets turnover of 2015 & -.055 & .197 & .899 \\
\hline earnings per share of 2015 EPS & .173 & .924 & .008 \\
\hline Cash ratio of 2015 & .119 & .893 & .016 \\
\hline Net cash flow per share from operating activities in 2015 & .879 & .111 & -.083 \\
\hline
\end{tabular}

Table 8 Component score coefficient matrix in 2015

\begin{tabular}{llll}
\hline & \multicolumn{3}{l}{ component } \\
\cline { 2 - 4 } & 1 & 2 & 3 \\
\hline current ratio of 2015 & .281 & -.047 & .033 \\
\hline quick ratio of 2015 & .282 & -.048 & .041 \\
\hline reciprocal of asset-liability ratio in 2015 & .269 & -.049 & .041 \\
\hline current asset turnover of 2015 & .044 & -.082 & .561 \\
\hline total assets turnover of 2015 & .043 & .012 & .522 \\
\hline earnings per share of 2015 EPS & -.045 & .514 & -.090 \\
\hline return on equity ROE(average) in 2015 & -.057 & .501 & -.087 \\
\hline Cash ratio of 2015 & .246 & -.019 & .014 \\
\hline Net cash flow per share from operating activities in 2015 & -.030 & .219 & .071 \\
\hline
\end{tabular}

Let factor 1 be F1, factor 2 be F2, and factor be F3, so,

$\mathrm{F} 1=-0.00006, \mathrm{~F} 2=0.00004, \mathrm{~F} 3=-0.00004$

$\mathrm{F}=(42.959 \% * \mathrm{~F} 1+23.352 \% * \mathrm{~F} 2+14.679 \% * \mathrm{~F} 3) / 80.990 \%=-0.00002754$ 
Table 9 Rotation component matrix in 2016

\begin{tabular}{llll}
\hline & \multicolumn{3}{l}{ Component } \\
\cline { 2 - 4 } & 1 & 2 & 3 \\
\hline current ratio of 2016 & .980 & -.046 & -.014 \\
\hline quick ratio of 2016 & .980 & -.033 & -.023 \\
\hline reciprocal of asset-liability ratio in 2016 & .924 & -.031 & -.042 \\
\hline current asset turnover of 2016 & -.152 & .880 & .082 \\
\hline total assets turnover of 2016 & -.060 & .930 & .125 \\
\hline earnings per share of 2016 EPS & .162 & .230 & .837 \\
\hline return on equity ROE(average) in 2016 & .076 & .457 & .734 \\
\hline Cash ratio of 2016 & .834 & -.171 & .200 \\
\hline Net cash flow per share from operating activities in 2016 & -.090 & -.116 & .598 \\
\hline
\end{tabular}

Table 10 Component score coefficient matrix in 2016

\begin{tabular}{llll}
\hline & \multicolumn{3}{l}{ component } \\
\cline { 2 - 4 } current ratio of 2016 & 1 & 2 & 3 \\
\hline quick ratio of 2016 & .286 & .048 & -.062 \\
\hline reciprocal of asset-liability ratio in 2016 & .287 & .058 & -.071 \\
\hline current asset turnover of 2016 & .272 & .059 & -.082 \\
\hline total assets turnover of 2016 & .015 & .498 & -.137 \\
\hline earnings per share of 2016 EPS & .043 & .525 & -.125 \\
\hline return on equity ROE(average) in 2016 & .011 & -.044 & .519 \\
\hline Cash ratio of 2016 & .009 & .110 & .400 \\
\hline Net cash flow per share from operating activities in 2016 & .220 & -.087 & .125 \\
\hline F1' & -.074 & -.215 & .448 \\
\hline
\end{tabular}

$\mathrm{F}^{\prime}=-0.00001, \mathrm{~F} 2^{\prime}=-0.00001, \mathrm{~F} 3^{\prime}=0.00001$

$F^{\prime}=-0.00050795$

Table 11 Rotation component matrix in 2017

\begin{tabular}{llll}
\hline & \multicolumn{3}{l}{ component } \\
\cline { 2 - 4 } & 1 & 2 & 3 \\
\hline current ratio of 2017 & .981 & -.026 & .000 \\
\hline quick ratio of 2017 & .979 & -.030 & .001 \\
\hline reciprocal of asset-liability ratio in 2017 & .736 & .011 & -.067 \\
\hline current asset turnover of 2017 & -.121 & .934 & .060 \\
\hline total assets turnover of 2017 & -.089 & .887 & .194 \\
\hline return on equity ROE(average) in 2017 & .041 & .137 & .921 \\
\hline Cash ratio of 2017 & -.046 & .118 & .935 \\
\hline
\end{tabular}

Table 12 Component score coefficient matrix in 2017

\begin{tabular}{llll}
\hline & \multicolumn{2}{l}{ component } \\
\cline { 2 - 4 } & 1 & 2 & 3 \\
\hline current ratio of 2017 & .296 & .018 & -.002 \\
\hline quick ratio of 2017 & .296 & .016 & -.001 \\
\hline reciprocal of asset-liability ratio in 2017 & .224 & .041 & -.047 \\
\hline current asset turnover of 2017 & -.006 & .521 & -.107 \\
\hline total assets turnover of 2017 & .002 & .475 & -.019 \\
\hline earnings per share of 2017 EPS & .011 & -.063 & .536 \\
\hline return on equity ROE(average) in 2017 & -.016 & -.078 & .548 \\
\hline Cash ratio of 2017 & .275 & .020 & .034 \\
\hline Net cash flow per share from operating activities in 2017 & .042 & .251 & -.048 \\
\hline
\end{tabular}

F1"=0, F2"=-0.00003, F3"=0.00001

$F "=-0.000000119$ 


\section{Comparison of Composite Score of Financial Performance before and after Private Placement}

Based on the financial performance composite score model, this paper calculates the financial performance composite score of sample companies for three years of private placement. From the perspective of financial performance average value, the financial performance of sample companies has not been improved in the year of private placement, but the decrease is 0.00555991 . After the issuance, the increase was 0.000507831; from the financial performance of the sample company in the year after the issuance and the year before the issuance, it can be found that the difference between the financial performance of the year after the private placement and the year before the issuance is positive, which shows that the performance of sample companies after private placements has improved to varying degrees.

\section{References}

[1] Gong Chun'en. Diversification or Diversified Deterioration? [D]. Guangxi University, 2017.

[2] Li Yanqing. Research on Performance of Private Placement of Shanghai A-share Listed Companies [D]. Jinan University, 2014.

[3] Chen Yixiao. Research on Behavior and Performance of Private Placement [J]. Communication of Finance and Accounting, 2013(08):28-30.

[4] Wang Wei. Research on the Effect of Private Placement of Substantial Shareholder on Long-term Performance of Listed Companies [D]. Nanjing Agricultural University, 2011.

[5] Fan Hongchen, Li Sifei. Institutional Investor of Private Placement: Wise or Bluffing [J]. Chinese Review of Financial Studies, 2016, 8 (06):80-93+123.

[6] Yan Guangquan, Wang Xiaoying. Research on Influencing Factors of Financial Effect of Private Placement in A-share Listed Companies [J]. CO-Operative Economy \& Science, 2016 (09):47-50.

[7] Huang Xiaowu, Wu Linxiu. A Comparative Study of Effect of Private Placement for Companies with Different Styles of Ownership: An Empirical Analysis Based on Event Study [J]. Journal of Hainan University (Humanities \& Social Sciences), 2015, 33 (06):39-47.

[8] Xu Xiaoxiao, Yang Yufeng, Wang Ruolin. Empirical Test of the Effect of Private Placement on Business Performance of Listed Companies [J]. Finance and Accounting Monthly, 2015(23):112-116.

[9] Ma Caihua, Wang Zixin. Research on Asset Injection and Entrenchment in Private Placement Interpretative Framework Based on Second Type Agency Theory [J]. Friends of Accounting, 2015(06):92-95.

[10] Wu Linxiu. A Comparative Study of Effect of Private Placement for Companies in Different Industries: An Empirical Analysis Based on Event Study [J]. Economic Vision, 2015(02):8-10+16. 